\title{
AEC-NASA TECH BRIEF
}

AEC-NASA Tech Briefs describe innovations resulting from the research and development program of the U.S. AEC or from AEC-NASA interagency efforts. They are issued to encourage commercial application. Tech Briefs are published by NASA and may be purchased, at 15 cents each, from the Clearinghouse for Federal Scientific and Technical Information, Springfield, Virginia 22151.

\section{Superconductivity in Zirconium-Rhodium Alloys}

The phenomenon of superconductivity in zirconiumrhodium alloys at cryogenic temperatures has been studied at Argonne National Laboratory.

In the work, metallographic studies and transition temperature measurements were made with zirconiumrhodium alloys that had been isothermally annealed and water-quenched. The results clarify both the solid-state phase relations at the $\mathrm{Zr}$-rich end of the $\mathrm{Zr}-\mathrm{Rh}$ alloy system and the influence upon the superconducting transition temperature, $T_{c}$, of structure and composition. The data clearly demonstrated that superconductivity in the $\mathrm{Zr}-\mathrm{Rh}$ system is sensitively dependent upon both composition and structure. For martensitic $\alpha, \omega$, and $\beta$ phases, $T_{c}$ increases with increasing $\mathrm{Rh}$ concentration. Rhodium is only slightly soluble in $\alpha-\mathrm{Zr}$, if at all, and thus has little or no effect on the transition temperature of the $\alpha$ phase. An intermediate phase, $\mathrm{Zr}_{2} \mathrm{Rh}$, has a $\mathrm{T}_{\mathrm{c}}$ equal to $10.8^{\circ} \mathrm{K}$, while another phase, $\mathrm{ZrRh}$, is normal down to. $1.7^{\circ} \mathrm{K}$.

Alloys were prepared from zirconium crystal bar and $99.9+\%$ pure $\mathrm{Rh}$ by arc-melting on a watercooled hearth in an inert gas atmosphere. The alloys were then given a homogenization heat treatment for 72 hours at $1000^{\circ} \mathrm{C}$ and water-quenched. Specimens were then cut from the homogenized castings and isothermally annealed at temperatures between $600^{\circ}$ and $1200^{\circ} \mathrm{C}$ for 72 to 168 hours. For all heat treatments, the specimens were wrapped in zirconium foil and sealed in an inert gas atmosphere inside quartz capsules. After all heat treatments, the alloys were quenched by breaking the capsules under water. The phases present in the quenched alloys were identified by optical and X-ray metallography. Diffraction patterns were obtained with a $114.6 \mathrm{~mm}$-diameter DebyeScherrer camera using either $\mathrm{CuK}-\alpha$ or $\mathrm{CrK}-\alpha$ radiation. The lattice parameters of the $\mathrm{Zr}_{2} \mathrm{Rh}$ and $\omega$ phases were determined by a least-squares computer program. Superconducting transition temperatures were determined from magnetic permeability measurement in a 10 oersted field.

\section{Notes:}

1. The study, "Superconductivity in ZirconiumRhodium Alloys," has been published in a Technical Note, by S. T. Zegler, J. Phys. Chem. Solids, Pergamon Press, 1965, vol. 26, p 1347-1349.

2. This study may be of widespread interest, since superconductivity has application in ore beneficiation; chemical, physical, medical, and biological research; and electronic devices.

3. Inquiries concerning this innovation may be directed to:

Office of Industrial Cooperation

Argonne National Laboratory

9700 South Cass Avenue

Argonne, Illinois 60439

Reference: B69-10010

Source: S. T. Zegler

Metallurgy Division

Argonne National Laboratory

(ARG-10223)

\section{Patent status:}

Inquiries about obtaining rights for commercial use of this innovation may be made to:

Mr. George H. Lee, Chief

Chicago Patent Group

U.S. Atomic Energy Commission

Chicago Operations Office

9800 South Cass Avenue

Argonne, Illinois 60439
This document was prepared under the sponsorship of the Atomic Energy Commission and/or the National Aeronautics and Space Administration. Neither the United States Government nor any person acting on behalf of the United States Government assumes any liability resulting from the use of the information contained in this document, or warrants that the use of any information, apparatus, method, or process disclosed in this document may not infringe privately owned rights. 